\title{
Grapevine Leaf Application of Steinernema yirgalemense to Control Planococcus ficus in Semi-field Conditions
}

\author{
T. Platt ${ }^{1}$, N.F. Stokwe ${ }^{1,2}$, A.P. Malan ${ }^{1, *}$ \\ (1) Department of Conservation Ecology and Entomology, Stellenbosch University, Private Bag X1, Matieland 7602, South \\ Africa \\ (2) Agricultural Research Council (ARC), Infruitec-Nietvoorbij, Private Bag X5026, Stellenbosch, 7599, South Africa
}

Submitted for publication: August 2018

Accepted for publication: October 2018

Key words: above ground; adjuvants, vine mealybug, above-ground, Zeba ${ }^{\circledR}$, Nu-Film- $\mathrm{P}^{\circledR}$, entomopathogenic nematodes

\begin{abstract}
The vine mealybug, Planococcus ficus Signoret (Hemiptera: Pseudococcidae), is a key insect pest of South African grapevine. The ability of mealybugs to avoid or resist the action of chemical pesticides has led to the investigation of alternative control methods, such as the application of entomopathogenic nematodes (EPNs). However, EPN application faces challenges, due to the maladaptation of EPN species to aboveground conditions. In this study, the ability of adjuvants to improve the control of $P$. ficus in grapevine using an indigenous nematode species, Steinernema yirgalemense, was investigated. A trial was performed to assess EPN survival on grapevine foliage, when applied in the morning (high humidity / low temperature) compared with in the afternoon (high temperature / low humidity). In a semi-field trial, the combination of adjuvants Zeba ${ }^{\circledR}$ and Nu-Film-P ${ }^{\circledR}$ resulted in $66 \%$ control of $P$. ficus after $48 \mathrm{~h}$, compared to the use of Zeba ${ }^{\circledR}$ alone (43\%), and EPNs alone (28\%). Additionally, lower concentrations of EPNs showed predictably lower mortality rates of $\boldsymbol{P}$. ficus. Significantly, higher EPN survival was recorded at each time interval in the morning, compared with the corresponding interval in the afternoon. This study demonstrates the ability of $S$. yirgalemense, when applied with adjuvants and at an appropriate time of day, to control $P$. ficus on grapevine, under semi-field conditions.
\end{abstract}

\section{INTRODUCTION}

Mealybugs are scale insects of the family Pseudococcidae, notable for the waxy excretion that covers the bodies of the nymphs and females (Downie \& Gullan, 2004). They are also important pests of South African agriculture (Annecke \& Moran, 1982; Prinsloo \& Uys, 2015). These include the obscure mealybug Pseudococcus viburni (Signoret) on pome fruit (Wakgari \& Giliomee, 2004), the citrus mealybug Planococcus citri (Risso) on citrus (Hattingh et al., 1998), and the vine mealybug, Planococcus ficus (Signoret) on grapevine (Walton, 2003; De Villiers \& Pringle, 2007).

Planococcus ficus causes damage to grapevines by feeding on phloem, diverting resources from fruit production, and reducing yield. They also produce honeydew, which encourages the growth of sooty mould and serve as vectors for grape vine leafroll associated virus-3 (GLRaV-3), a closterovirus (Cabaleiro \& Segura, 1997; Millar, 2002). Planococcus ficus is the pre-eminent mealybug pest of grapevines in South Africa, being able to feed on all parts of the vine at various times of the year, producing more honeydew, and having a faster generation time (with more eggs laid and faster development) than do similar species
(Daane et al., 2003, 2008). Populations of P. ficus undergo seasonal migration on grapevine, receding downwards onto the trunk and roots as leaves fall in winter months, and moving upwards to the branches and leaf buds as foliage re-emerges in spring and summer (Walton, 2003). The cryptic lifestyle of the vine mealybug (residing in crevices and under raised grapevine bark), as well as the hydrophobic waxy coating covering nymphs and females, prevents effective contact with insecticides, thus posing problems for control by means of traditional chemical methods (Walton \& Pringle, 2004).

Entomopathogenic nematodes (EPNs) are roundworms, typically of the families Steinernematidae and Heterorhabditidae, which are characterized by parasitism of soil-based insect life stages (Adams \& Nguyen, 2002). The ability of EPNs to cause mortality in insects has led to significant interest in their use as potential biocontrol agents, with several products having been developed and used successfully in the control of subterranean pest insect life stages (Wilson \& Gaugler, 2004). However, attempts to apply EPNs for the control of foliage-based pest insect life stages have been considerably less successful treatment of

*Corresponding author: E-mail address: apm@sun.ac.za

Acknowledgments: The authors would like to thank Winetech, the South African Table Grape Industry (SATI), and Technology and Human Resources for Industry Programme (THRIP grant number: TP14062571871) for funding of the project. We also like to thank D.G. Nel for assistance with statistical analysis 
soil-borne pests (Shapiro-Ilan et al., 2006; Platt 2017; Platt et al 2018a, b). EPNs are soil-inhabiting organisms that are intolerant to (various degrees of) excessive temperature (Grewal et al., 1994; Wright et al., 2005), exposure to UV radiation (Gaugler \& Boush, 1978; Gaugler et al., 1992), and insufficient levels of humidity (Glazer, 1992; Glazer et al., 1992a, b). IJs also rely on a thin film of water for mobility, and desiccation inhibits the ability of the nematode to find prey (Norton, 1978; Glazer, 2002). The characteristics mentioned severely limit the use of EPNs to control insect life stages when applied to foliage, as the reduced survival and mobility inhibit the former's ability to locate and infect the targeted pest. Additionally, the tolerance of each EPN species to each of these environmental factors varies, based on the species concerned (Glazer, 1992). As such, EPN application on the pests of foliage has yielded mixed results, with EPNs being most successfully used on pests in sheltered or cryptic habitats, including undercover conditions or in the glasshouse, and in the boreholes of the leaf-mining, or stemboring, insect life stages (Arthurs et al., 2004).

The improvement of pesticide application, be it chemical or biological, has tended to focus on such areas as application technology (Georgis, 1990; Lello et al., 1996; Beck et al., 2014) and the addition of adjuvants, consisting of chemicals that alter the physical properties of pesticide treatments. Adjuvants that have commonly been used, with success, to enhance EPN applications on foliage include thickeners, surfactants, evaporation retardants, and antidesiccants (Webster \& Bronskill, 1968; MacVean et al., 1982; Shapiro et al., 1985; Glazer et al., 1992a; Head et al., 2004; Schroer \& Ehlers, 2004). A metastudy by Arthurs et al. (2004) assessed existing studies on the efficacy of EPNs, in which it was established that the addition of adjuvants to EPN solutions improved deposition onto foliage (Mason et al., 1998), as well as survival and control, compared with the application of water alone (MacVean et al., 1982; Shapiro et al., 1985; Glazer et al., 1992a, b). The adjuvants mentioned have shown promise in increasing the efficacy of foliar EPN applications, although their commercialisation remains slow (Arthurs et al., 2004; Shapiro-Ilan et al., 2006).

Previous research, including that of Van Niekerk and Malan (2012;2015), has assessed the ability of EPNs to control South African mealybugs. They compared the efficacy of two indigenous EPN species, Steinernema yirgalemense Nguyen, Tesfamariam, Gozel, Gaugler \& Adams and Heterorhabditis zealandica Poinar, in controlling populations of the citrus mealybug $P$. citri. EPN treatments, both with and without adjuvants, were formulated and applied to $P$. citri females in the greenhouse and under semi-field conditions. It was found that the addition of $\mathrm{Zeba}^{\circledR}$, a superabsorbent polymer based on corn-starch, was able significantly to increase the ability of $S$. yirgalemense to cause mortality in female $P$. citri by protecting the EPNs from the prevailing environmental conditions in a semi-field trial.

Le Vieux and Malan $(2013,2015)$ examined the ability of $S$. yirgalemense and $H$. zealandica to control $P$. ficus in the soil, the given EPN's established ability to control soilbased organisms, and the fact that $P$. ficus are found on grapevine roots. Steinernema yirgalemense was found to be more effective in controlling populations of $P$. ficus in sand column tests than was $H$. zealandica, with neither EPN species being adversely affected by exposure to imidacloprid (thus making them both potential candidates for an integrated pest management). However, the study concerned only assessed the ability of EPNs to control P. ficus on roots, where the latter are only found during the coldest months, and in low numbers. Planococcus ficus populations move upwards on grapevine trunks during the summer months, congregating on leaves and buds, and increasing in number as the temperatures increase, with the populations declining in winter (Berlinger, 1977; Walton, 2003). This would limit an EPN strategy to control P. ficus that was purely soil-based.

Platt et al. (2018a) in a laboratory-based bioassay showed mortality of $90 \%$, using Heterorhabditis noenieputensis Malan, Knoetze \& Tiedt, compared to $S$. yirgalemense with $70 \%$ control. It was also shown that the combination of adjuvants, Zeba ${ }^{\circledR}$ and Nu-Film- $\mathrm{P}^{\circledR}$, resulted in significantly more $S$. yirgalemense being deposited on grapevine leaf discs. Applying $S$. yirgalemense in combination with both adjuvants on $P$. ficus infested leaf discs in a growth chamber, resulted in $84 \%$ mortality. Similar results were observed in a glasshouse trial, with $88 \%$ control of $P$. ficus on leaf discs hung on potted vines (Platt et al., 2018b). These studies demonstrated the potential of a combination of $S$. yirgalemense and adjuvants to give significant control of $P$. ficus on grapevine foliage in semi-natural conditions on vine leaves.

The objective of the current study was to investigate the effect of two adjuvants on the efficacy of $S$. yirgalemense for the control of $P$. ficus on foliage under semi-field conditions. Each adjuvant (and combinations thereof) was assessed for their effects on EPN efficacy in foliar application, as well as for their ability to increase EPN deposition and survival on grapevine leaves in a vineyard. The effect of variable nematode concentrations in nematode-adjuvant treatments was also investigated.

\section{MATERIALS AND METHODS \\ Source of nematodes and insects}

Steinernema yirgalemense Nguyen, Tesfamariam, Gozel, Gaugler \& Adams, used originated from samples that were collected locally, maintained and cultured at Stellenbosch University (Malan et al. 2011). IJs were cultured in vivo by means of infecting larvae of the mealworm beetle Tenebrio molitor L. (Tenebrionidae: Coleoptera) and kept at $25^{\circ} \mathrm{C}$ until their emergence and before they were transferred to modified White traps (Woodring \& Kaya 1988). The IJs harvested from the White traps were transferred to vented flasks, where they were kept at $14^{\circ} \mathrm{C}$, in keeping with the guidelines set out by Kaya \& Stock (1997). These flasks were gently agitated once a week to improve aeration. IJs for the experimentation were used within one week of emergence. All experiments were repeated on a different test date, with a fresh batch of nematodes. Each insect was dissected and investigated by using a dissecting microscope to confirm that mortality equals infection by nematodes.

\section{Adjuvant field trial}

To compare the effects of two adjuvants on the ability of $S$. yirgalemense to infect and control P. ficus, an experiment 
was conducted at the Welgevallen Experimental Farm in Stellenbosch, Western Cape province, South Africa. Grapevine leaves were cut into pieces to fit Petri dishes with a diameter of $13 \mathrm{~cm}$. Two adjuvants were used, Zeba ${ }^{\circledR}$ [88\% starch-g-poly (2-propenamide-co-2-propenoic acid) potassium salt, Tongaat Hulett Starch] (United Phosporus Ltd) and Nu-Film-P ${ }^{\circledR}$ (poly-1-p-menthene) (Hygrotech Properties). Nematode suspensions were formulated at 4000 $\mathrm{IJ} / \mathrm{ml}$ and $\mathrm{Zeba}^{\circledR}$ was added at a concentration of $0.03 \%$, and Nu-Film-P ${ }^{\circledR}$ at $0.06 \%$. The treatments were prepared $1 \mathrm{~h}$ prior to the onset of the trial.

For each treatment, eight Petri dishes were prepared, each containing a grapevine leaf, to which eight female $P$. ficus were added, using 64 mealybugs per treatment. The different treatments applied include, Zeba ${ }^{\circledR}$ only, Zeba ${ }^{\circledR}+\mathrm{Nu}-\mathrm{Film}-\mathrm{P}^{\circledR}$ and nematodes without adjuvants, with a control of water only (without adjuvants). In a previous study, Platt et al. (2018b) showed that Nu-Film- $\mathrm{P}^{\circledR}$ alone did not significantly improve the deposition of IJ on grapevine leaves, over the applications of Zeba alone and therefore was not included as a separate treatment. Treatments were applied to the Petri dishes via a calibrated handheld sprayer, after which the leaves were removed and left for 3 min to eliminate excess runoff. Each leaf was then placed in a fine mesh pocket and sealed, in order to contain the mealybugs. The pockets were hung in the vineyard using a randomised design, distributed between four rows of vines. Each pocket was hung on alternating vines, $150 \mathrm{~cm}$ from the soil, with the outer rows and the first three vines of each row excluded to avoid edge effects. Ambient temperature and humidity were monitored in the vineyard using iButtons ${ }^{\circledR}$ (Maxim Integrated) placed in their own, separate mesh pocket. After $24 \mathrm{~h}$, the pockets were retrieved and the mealybugs were removed from the leaves, rinsed, placed in Petri dishes lined with moistened filter paper, and incubated at $25^{\circ} \mathrm{C}$. Mealybug mortality was assessed for $48 \mathrm{~h}$ after application.

\section{Concentration field trial}

The effect of IJ concentration on the ability of $S$. yirgalemense to kill P. ficus when formulated with Zeba ${ }^{\circledR}$ and Nu-Film-P ${ }^{\circledR}$ was investigated. Mesh pockets, grapevine leaves and mealybugs were prepared as previously described for the adjuvant field trial. The treatments applied included formulations of $S$. yirgalemense at concentrations of 1000 , 2000 and $3000 \mathrm{IJ} / \mathrm{ml}$, compared to a control treatment of water only. Each treatment (including the control of water only) was formulated with $0.03 \% \mathrm{Zeba}^{\circledR}$ and $0.06 \% \mathrm{Nu}-$ Film- $\mathrm{P}^{\circledR}$. After preparation, the leaves were placed in mesh pockets, hung in the vineyard, and assessed after $48 \mathrm{~h}$.

\section{Morning and afternoon outdoor applications}

The effects of adjuvants on nematode desiccation under field conditions were assessed. A grapevine at Welgevallen Experimental Farm was pre-moistened using a backpack sprayer of water. A suspension was consequently applied containing $S$. yirgalemense at a concentration of 2000 $\mathrm{IJs} / \mathrm{ml}, \mathrm{Zeba}^{\circledR}(0.03 \%)$ and Nu-Film-P ${ }^{\circledR}(0.06 \%)$, using a calibrated handheld sprayer, and allowed to stand for $3 \mathrm{~min}$ to eliminate excess runoff. At $0,30,60,120$ and $240 \mathrm{~min}$ post-application, three leaves were removed from the plant and two $2 \mathrm{~cm}^{2}$ discs were cut from each leaf, for a total of six discs per time interval. Each disc was rinsed with $5 \mathrm{ml}$ tap water, whereupon the number of live and dead nematodes was recorded. The application, which was done at 8:00 in the morning, was repeated at 14:00 in the afternoon. Nematodes that did not respond to either light or prodding were recorded as dead.

\section{Data analysis}

Analysis of data obtained from all the trials was conducted on STATISTICA statistical analysis software version 13 (TIBCO Inc., 2017). Data from the adjuvant and concentration field trials were analysed using the ANOVA, while data from the outdoor deposition trial were analysed using generalised nonlinear models (GLZs), using a Poisson distribution and a log link function. For each experiment, the data from both trial dates were compared by means of an ANOVA to confirm the significant differences. Kruskall-Wallis tests were performed to confirm the results of the ANOVA and GLZ analyses. Bonferroni's test was applied for the posthoc comparison of means. All significant differences were calculated to $95 \%$ probability level.

\section{RESULTS}

\section{Adjuvant field trial}

The mean temperature at EPN application was $19.4^{\circ} \mathrm{C}$, with a min of $13.6^{\circ} \mathrm{C}$ and a max of $31.7^{\circ} \mathrm{C}$, during the exposure period. The average temperature over the exposure period was $21.8^{\circ} \mathrm{C}$. The relative humidity $(\mathrm{RH})$ was recorded as $69.5 \%$ at EPN application, ranging between 32.9 and $94.8 \%$ over the duration of the trial, with an average of $67.5 \%$ over the exposure period.

No significant difference was found between the main effects of treatment and time, allowing data from the two trials to be pooled. The one-way ANOVA analysis of percentage mortality of $P$. ficus post-exposure to each of the $S$. yirgalemense-containing treatments and the control of water only, showed a significant difference in mortality between each treatment $\left(\mathrm{F}_{(3,120)}=144.94, \mathrm{p}<0.01\right)$. Each nematode treatment giving significantly higher mortality than the control $(5.5 \% \pm 2 \%)$ after $48 \mathrm{~h}$. Both adjuvant-based IJ treatments gave significantly higher mortality than did the IJs alone $(28.1 \% \pm 2 \%)$, with Zeba ${ }^{\circledR}+\mathrm{Nu}-$ Film-P ${ }^{\circledR}$ being the most effective overall treatment $(66.4 \% \pm 4 \%)$, followed by Zeba $^{\circledR}$ alone (43.0\% $\pm 3 \%$ ) (Fig. 1).

\section{Concentration field trial}

The average temperature at EPN application (08:00) was $20.9^{\circ} \mathrm{C}$, with the $\mathrm{RH}$ at $65.3 \%$. Temperatures during the trial period ranged between $13.6^{\circ} \mathrm{C}$ and $31.5^{\circ} \mathrm{C}$, with a mean of $21.5^{\circ} \mathrm{C}$ during the $48 \mathrm{~h}$ exposure period, and with the $\mathrm{RH}$ ranging between $32.1 \%$ and $94.8 \%$, with a mean of $67.9 \%$ during the exposure period (Fig. 2A).

The two field trials were analysed, with treatment and date as the main effects. As no significant differences were found between the two experiments, the data were pooled. The one-way ANOVA analysis, which compare the effect on mealybug mortality of three different concentrations of $S$. yirgalemense with $\mathrm{Zeba}^{\circledR}+\mathrm{Nu}-$ Film- ${ }^{\circledR}$, showed each treatment to be significantly different to the others 


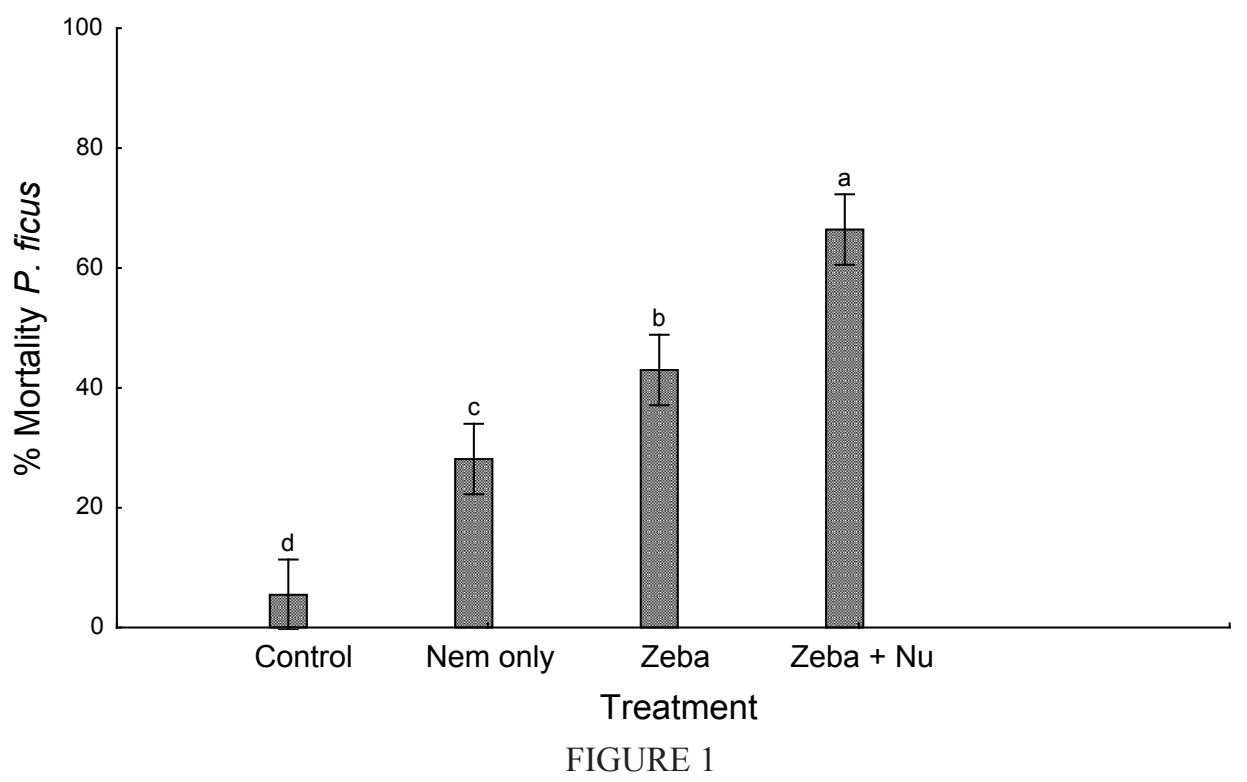

Mean percentage (95\% confidence interval) mortality of Planococcus ficus on grapevine leaves, treated with $4000 \mathrm{IJ} / \mathrm{ml}$ Steinernema yirgalemense with Zeba only and both Zeba $+\mathrm{Nu}-$ Film- $\mathrm{P}^{\circledR}$ and the nematodes only, with a control of water only (without adjuvants). Leaves were exposed in mesh pockets in a vineyard for $24 \mathrm{~h}$. Mortality was assessed $48 \mathrm{~h}$ total postapplication (one-way ANOVA: $\mathrm{F}_{(3,120)}=144.94, \mathrm{p}<0.01$ ). Means of bars labelled with the same letter are not significantly different from one another $(\mathrm{p}<0.05)$.

$\left(\mathrm{F}_{(3,112)}=46.467, \mathrm{p}<0.01\right)$. The treatment with the highest concentration of $3000 \mathrm{IJ} / \mathrm{ml}$ being the most effective $(43.8 \% \pm 4 \%)$ after $48 \mathrm{~h}$, followed by the treatments with concentrations of $2000 \mathrm{IJs} / \mathrm{ml}(32.0 \% \pm 3 \%)$ and $1000 \mathrm{IJS} /$ $\mathrm{ml}(20.3 \% \pm 4 \%)$, compared with the control $(7.8 \% \pm 3 \%)$ (Fig. 2B).

\section{Morning and afternoon application}

For the morning trial, temperature and humidity at the start of the trial $(8: 00)$ were $14.6^{\circ} \mathrm{C}$ and $93.2 \%$, respectively. Temperatures ranged between 15.0 and $34.9^{\circ} \mathrm{C}$ during the exposure period, with an average temperature of $25.2^{\circ} \mathrm{C}$. The $\mathrm{RH}$ ranged from 34.0 to $93.7 \%$, with an average of $60.2 \%$ during the trial period (Fig. 3A). Conditions differed in the afternoon trial, with the temperature and $\mathrm{RH}$, at the time of application (14:00), being $31.0^{\circ} \mathrm{C}$ and $39.9 \%$, respectively. Temperatures during the 4-h period ranged between 20.4 and $31.0^{\circ} \mathrm{C}$, with an average of $26.8^{\circ} \mathrm{C}$. The $\mathrm{RH}$ ranged between 40.6 and $64.6 \%$, with an average of $46.8 \%$ over the trial period (Fig. 3B).

A comparison of the counts of live nematodes collected from the leaves treated with EPNs and adjuvants, overall, showed the number of live $S$. yirgalemense retrieved from leaf discs differed significantly between 8:00 and 14:00 $(\mathrm{p}<0.01)$, and by time interval post-application $(\mathrm{p}<0.01)$ (Fig. 3C). In the morning application, 4.7 nematodes were recovered after $4 \mathrm{~h}$, in comparison with the 6.1 nematodes that were recovered immediately after application. In the afternoon application, 4.5 nematodes were retrieved directly after application, in comparison to the 0.5 nematodes retrieved $4 \mathrm{~h}$ later.

\section{DISCUSSION}

The results demonstrate that the addition of $\mathrm{Zeba}^{\circledR}$ and NuFilm- ${ }^{\circledR}$ to $S$. yirgalemense treatments has a positive effect on the control of P. ficus on foliage. The benefits of each adjuvant appear to be additive. The Nu-Film- $\mathrm{P}^{\circledR}$ alone treatment increased $P$. ficus mortality by $22 \%$ compared to the control, with the treatment containing Nu-Film- ${ }^{\circledR}$ and Zeba $^{\circledR}$ giving a slightly higher mortality than did Zeba ${ }^{\circledR}$ alone. This is concurrence with a laboratory and glasshouse study of Platt et al. (2018a, b), in which the application of adjuvants on grapevine leaves improved the control of P. ficus. These findings are in contrast to that of Van Niekerk and Malan (2014b; 2015), who assessed these adjuvants and showed that all nematode-containing treatments improved $P$. citri mortality, but that the combination of $\mathrm{Zeba}^{\circledR}$ and NuFilm- $\mathrm{P}^{\circledR}$ was the only treatment to offer significantly higher mortality of $P$. citri on citrus than did the nematodes alone. The difference in results attained may be ascribed to the different structures of the leaves used, with citrus leaves being firmer and waxier, on average, than are grapevine leaves, on average. Nu-Film- $\mathrm{P}^{\circledR}$ is a spreader and sticker, and, as such, might have been more effective on grapevine leaves of, which the surfaces are less hydrophobic.

A key concern of pesticide applications against the vine mealybug is their tendency to occupy cryptic habitats, thus shielding them from pesticidal application. A future study should investigate the ability of EPNs to infect female mealybugs by means of actively moving into cryptic habitats where the insects reside, which is also a more conducive microhabitat for the nematodes themselves, thus offering a significant potential advantage over the use of chemical pesticides.

In this study, an experiment was carried out to determine the effects of varying $S$. yirgalemense concentration on 

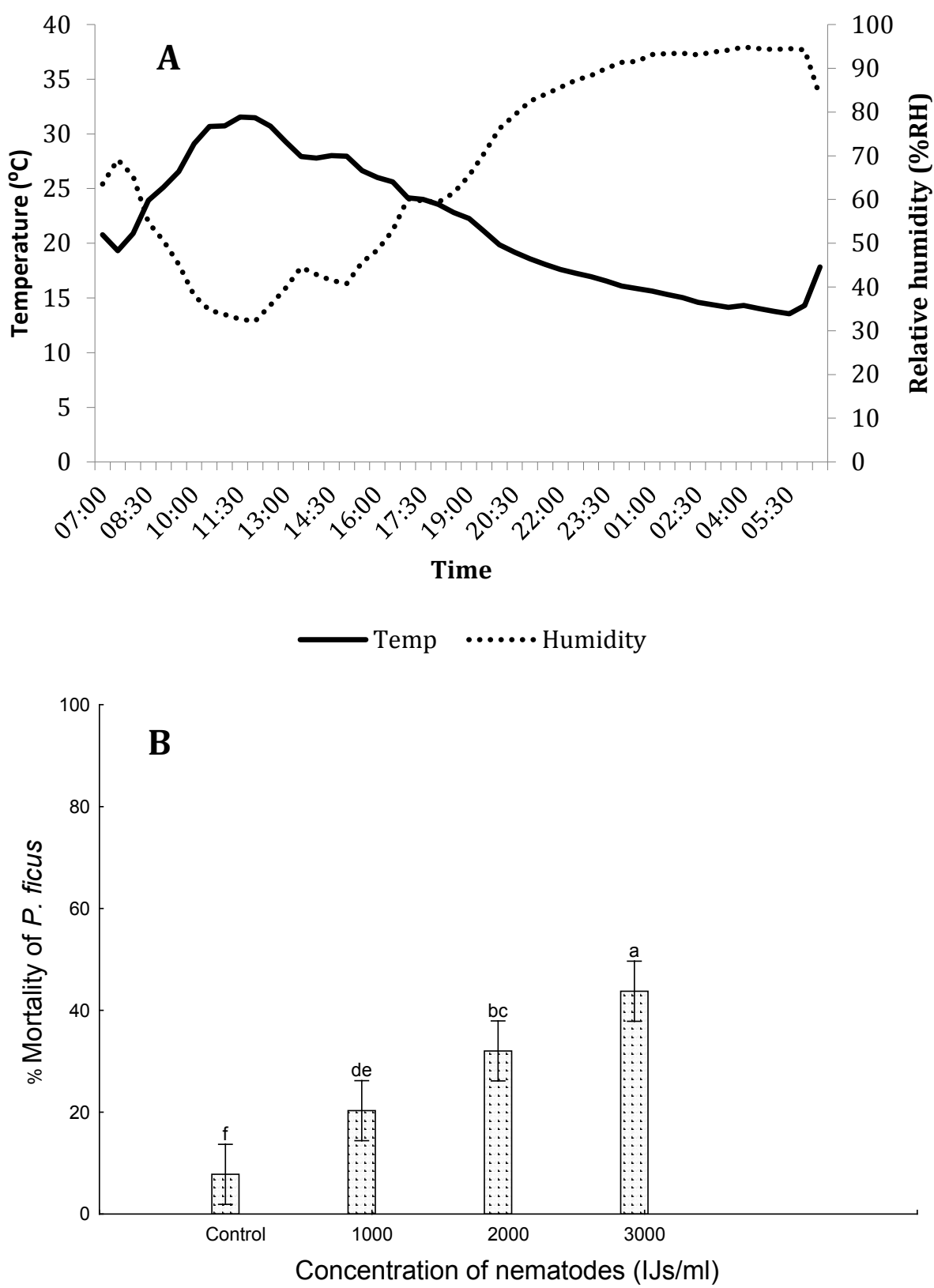

FIGURE 2

A: Climatic data recorded over the first $24 \mathrm{~h}$ duration of the concentration trial. B: Mean percentage (95\% confidence interval) mortality of female Planococcus ficus, using three different concentrations (1000, 2000 and 3000 IJs per ml) of Steinernema yirgalemense, $\mathrm{Zeba}^{\circledR}$ and $\mathrm{Nu}-\mathrm{Film}-\mathrm{P}^{\circledR}$ and a control of water only. Mortality was assessed 48 h post-application (one-way ANOVA: $\left.\mathrm{F}_{(3,112)}=46.467, \mathrm{p}<0.01\right)$. Means of bars sharing a letter are not significantly different from one another.

the mortality of female $P$. ficus. Each of the three EPN concentrations used $(1000,2000$ and $3000 \mathrm{IJ} / \mathrm{ml})$ resulted in significantly higher mortality after $48 \mathrm{~h}$. Planococcus ficus mortality at $1000 \mathrm{IJs} / \mathrm{ml}$ differed significantly from the control, with the mortality at $2000 \mathrm{IJs} / \mathrm{ml}$ being $32 \%$, and with it being $44 \%$ at $3000 \mathrm{IJ} / \mathrm{ml}$. The above suggests that EPN concentration can be increased for predictable increases in P. ficus mortality under such conditions. The suggestion is in keeping with the research that has been conducted by Le Vieux and Malan (2013), who assessed the effect of increasing the concentration of three EPN species on individual $P$. ficus mortality. A similar increase in mortality was also observed as the EPN concentration was increased from 0 to $80 \mathrm{IJs}$ per mealybug. This is comparable to the increase in mortality observed per $1000 \mathrm{IJs} / \mathrm{ml}$ in Figure 1. By contrast, De Waal (2008) observed no significant difference between the mortality caused at 80 to $160 \mathrm{IJS} /$ $\mathrm{ml}$, and the mortality caused at $640 \mathrm{IJ} / \mathrm{ml}$, when increasing concentrations of $H$. zealandica applied to diapausing codling moth (C. pomonella) larvae. Future research should investigate the upper limit, if any, of increasing concentrations of $S$. yirgalemense on $P$. ficus mortality, when applied with $\mathrm{Zeba}^{\circledR}$ and Nu-Film- ${ }^{\circledR}$.

Additionally, the effect on EPN survival on foliage caused by the climatic differences observed in morning and afternoon applications was assessed. The mean temperature 

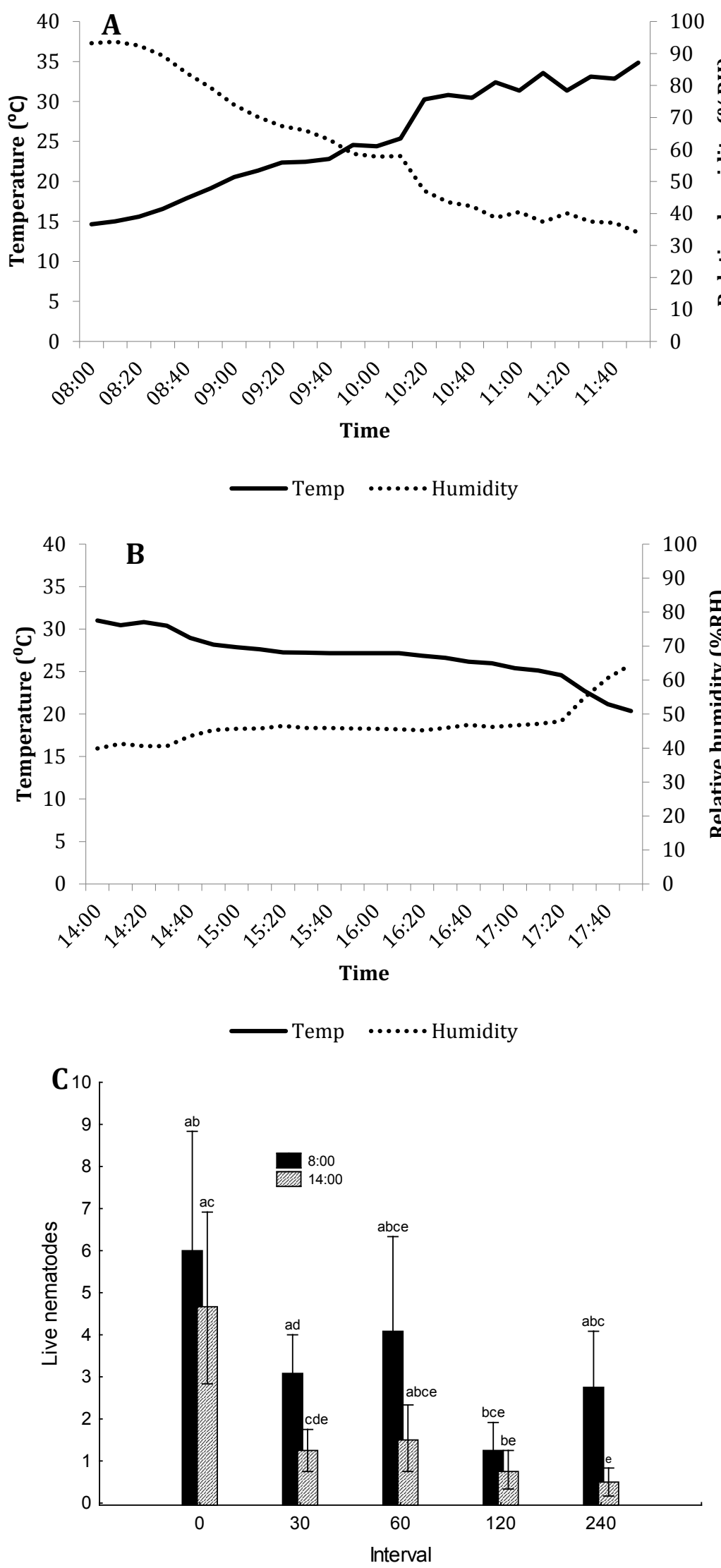

FIGURE 3

Climatic data recorded over the $4 \mathrm{~h}$ exposure time of the A: morning outdoor deposition trial and B: afternoon outdoor deposition trial. C: The mean number of nematodes collected from leaf discs at timed intervals post the application of a suspension of Steinernema yirgalemense, Zeba ${ }^{\circledR}$ and Nu-Film- $\mathrm{P}^{\circledR}$. Nematodes were applied to leaves using a handheld sprayer, at a concentration of $2000 \mathrm{IJs} / \mathrm{ml}$. The number of live nematodes present at each time interval was compared (Wald $\mathrm{X}^{2}(4)=$ $13.239, \mathrm{p}=0.017)$. Means of bars sharing a letter are not significantly different from one another. 
and humidity over the experimental period varied greatly, with the temperature at $14: 00$ being $16^{\circ} \mathrm{C}$ higher than at 8:00. The RH was also much lower at 14:00 (40\%), compared with at 8:00 (93\%). Overall, the foliar survival of EPNs was significantly lower when they were applied in the afternoon. Additionally, the number of living nematodes recovered from leaf discs in the afternoon was lower at all intervals, compared with the same intervals when applied in the morning trial. De Waal et al. (2017) observed similar findings with respect to the interaction between $\mathrm{H}$. zealandica and C. pomonella. They recorded mortality of 80 to $100 \%$ when the nematodes were applied to codling moth larvae at sunrise, compared with $<50 \%$ mortality when the nematodes were applied at sunset. In general, morning application appears to be superior to evening application with regard to EPN survival and infectivity.

These results illustrate the importance optimum environmental conditions for application, as adjuvants alone are insufficient to counter the effects of climatic conditions completely. In order to be effective, knowledge of the local climatic conditions, as well as of the temperature/humidity niche breadth of the EPN species used, is essential. In the case of $S$. yirgalemense, with the weather conditions at 8:00 being closer to the ideal for application than they were at 14:00 served to establish that $100 \% \mathrm{RH}$ and temperatures of around $25^{\circ} \mathrm{C}$ (Platt et al., 2018a, b) seemed to be ideal for the EPN infection of female $P$. ficus.

Future research would be useful in determining the relationship between temperature and humidity. Applications in the case of the current study took place in March 2017, and, over the $24 \mathrm{~h}$ period assessed, the temperature and humidity conditions did not align ideally - the temperatures at maximum humidity were lower than the ideal, and the humidity at optimal temperatures (Platt et al., 2018a, b) was also low. It would, therefore, be of interest to investigate the relationship between temperature and humidity to determine the most important factor in terms of EPN success on foliage. Additionally, the effects of irrigation on the foliar application of EPNs in the control of $P$. ficus should be investigated. EPN survival on foliage can be improved when applications occur post-rainfall (Mráček, 2002). However, rain forecasting in South Africa is less reliable than it is elsewhere, such as in Europe. Downing (1994) demonstrated the potential of pre- and post-application irrigation when $H$. bacteriophora was applied in the control of two Coleopteran species on Kentucky bluegrass, achieving consistent pest mortality ( $>80 \%$ ), compared to unirrigated controls. This was supported by Odendaal et al. (2016), who found that increases in RH were, overall, found to be the most effective factor in the improving of EPN control over codling moth. Therefore, it would appear that EPN species should be selected for the expected temperature niche during which they will be applied, and application techniques should focus instead on maintaining the appropriate humidity levels within the application area for as long as possible.

One possible area of grape production that might synergise with EPN applications is the use of table grape vineyards covered with shade netting. Increasing global temperatures tend to lead to negative effects on wine grapes grown in hot regions. For example, Sémillon grapes demonstrate a decrease in the sugar content of grapes and photosynthesis when exposed to $40^{\circ} \mathrm{C}$ temperatures (Greer $\&$ Weston, 2010). Artificial shading methods are commonly employed in table grape vineyards to manage the prevailing temperature, after studies have been carried out to assess the impact of shading on wine grape vineyards. Cartechini \& Palliotti (1995), on assessing the effects of three levels of cover $(100 \%, 60 \%$ and $30 \%$ sunlight penetration) on the temperature and humidity in a Sangiovese vineyard, found that the temperature decreased, and the humidity increased in covered vineyards. Similar results have been demonstrated with regards to Shiraz (Caravia et al., 2016) and Sémillon grapes (Greer \& Weston, 2010). Besides their intended purpose in ameliorating conditions for wine grape development, artificial shading might also serve to ameliorate conditions for EPN activity by means of lowering temperatures and by means of (critically) causing relative humidity levels to increase. Platt et al. (2018c) showed the effective control of $P$. ficus on grapevine leaves using $S$. yirgalemense in both a growth chamber and in glasshouse experiments

Overall, the ability of an adjuvant-based $S$. yirgalemense treatment to obtain high mortality of female $P$. ficus, under semi-field conditions, is promising in terms of the development of a potential foliar biopesticide containing $S$. yirgalemense. Notably, however, the results concerned were obtained from the direct spraying of mealybugs, with work remaining to be done on developing an effective means of application for mealybug colonies living in cryptic habitats on grapevines. Nevertheless, the current study demonstrates that it is possible for high concentrations of $S$. yirgalemense to obtain $>65 \%$ mortality in female mealybugs on grapevine foliage, when with the addision adjuvants. It is also of important that application should be in a windows period during the day, in which optimal climate conditions are present. Research into techniques for maintaining optimal environmental conditions, for both grape and nematode, is the next step to be undertaken in the search for an effective nematode-based solution to the existing problems in this field.

\section{LITERATURE CITED}

Adams, B.J. \& Nguyen, K.B., 2002. Taxonomy and systematics. In: Gaugler, R. (ed). Entomopathogenic nematology. CAB International, Wallingford. pp. $1-34$.

Annecke, D.P. \& Moran, V.C., 1982. Insects and Mites of Cultivated Plants in South Africa. Butterworths, Durban.

Arthurs, S., Heinz, K.M. \& Prasifka, J.R., 2004. An analysis of using entomopathogenic nematodes against above-ground pests. Bul. Entomol. Res. 94, 297-306. doi: 10.1079/BER2003309

Beck, B., Brusselman, E., Nuyttens, D., Moens, M., Temmerman, F., Pollet, S., Van Weyenberg, S. \& Spanoghe, P., 2014. Improving the biocontrol potential of entomopathogenic nematodes against Mamestra brassicae: Effect of spray application technique, adjuvants and an attractant. Pest Manag. Sci. 70, 103-112. doi: 10.1002/ps.3533

Berlinger, M.J., 1977. The Mediterranean vine mealybug and its natural enemies in southern Israel. Phytoparasitica 5, 3-14. doi: 10.1007/ BF03179429 
Cabaleiro, C. \& Segura, A., 1997. Some characteristics of the transmission of grapevine leafroll associated virus 3 by Planococcus citri Risso. Eur. J. Plant. Pathol. 103, 373-378. doi: 10.1023/A:1008619523666

Caravia, L., Collins, C., Petrie, P.R. \& Tyerman, S.D., 2016. Applications of shade treatments during Shiraz berry ripening to reduce the impact of high temperature. Aust. J. Grape Wine Res. 22, 422-437. doi: 10.1111/ ajgw. 12248

Cartechini, A. \& Palliotti, A., 1995. Effects of shading on vine morphology and productivity and leaf gas exchange characteristics in grapevines in the field. Am. J. Enol. Vitic. 46, 227-234.

Daane, K.M., Cooper, M.L., Triapitsyn, S.V., Walton, V.M., Yokota, G.Y., Haviland, D.R., Bentley, W.J., Godfrey, K.E. \& Wunderlich, L.R., 2008. Vineyard managers and researchers seek sustainable solutions for mealybugs, a changing pest complex. Calif. Agr. 62, 167-176. Doi: 10.3733/ ca.v062n04p167

Daane, K.M., Malakar-Kuenen, R., Guillen, M., Bentley, W.J., Bianchi, M. \& Gonzalez, D., 2003. Abiotic and biotic pest refuges hamper biological control of mealybugs in California vineyards. In: 1st Intern. Symp. on Biological Control of Arthropods, Honolulu. pp. 389 - 398.

De Villiers, M. \& Pringle, K.L., 2007. Seasonal occurrence of vine pests in commercially treated vineyards in the Hex River Valley in the Western Cape Province, South Africa. Afr. Entomol. 15, 241. doi: 10.4001/1021$3589-15.2 .241$

De Waal, J.Y., 2008. Entomopathogenic nematodes (Rhabditida: Steinernematidae and Heterorhabditidae) for the control of the codling moth Cydia pomonella (L.) under South African conditions. Thesis, Stellenbosch University, Private Bag X1, 7602 Matieland (Stellenbosch), South Africa.

De Waal, J.Y., Addison, M.F. \& Malan, A.P., 2017. Potential of Heterorhabditis zealandica (Rhabditida: Heterorhabditidae) for the control of codling moth, Cydia pomonella (Lepidoptera: Tortricidae) in semi-field trials under South African conditions. Int. J. Pest. Manag. 63, 1-9. doi: $10.1080 / 09670874.2017 .1342149$

De Waal, J.Y., Malan, A.P. \& Addison, M.F., 2013. Effect of humidity and a superabsorbent polymer formulation on the efficacy of Heterorhabditis zealandica (Rhabditida: Heterorhabditidae) to control codling moth, Cydia pomonella (L.) (Lepidoptera: Tortricidae). Biocontrol. Sci. Techn. 23, 6278. doi: 10.1080/09583157.2012.736472

Downie, D.A. \& Gullan, P.J., 2004. Phylogenetic analysis of mealybugs (Hemiptera: Coccoidea: Pseudococcidae) based on DNA sequences from three nuclear genes, and a review of the higher classification. Syst. Entomol. 29, 238-259. doi: 10.1111/j.0307-6970.2004.00241.x

Downing, A.S., 1994. Efficacy of entomopathogenic nematodes (Rhabditida: Heterorhabditidae) against white grubs (Coleoptera: Scarabaeidae). J. Econ. Entomol. 83, 643-646. doi: 10.1093/jee/87.3.643

Forst, S. \& Clarke, D., 2002. Bacteria-nematode symbiosis. In: Gaugler, R. (ed). Entomopathogenic nematology. CAB International, Wallingford. pp. $57-78$.

Gaugler, R., Bednarek, A. \& Campbell, J.F., 1992. Ultraviolet inactivation of heterorhabditid and steinernematid nematodes. J. Invertebr. Pathol. 160, 155-160. doi: 10.1016/0022-2011(92)90026-Z

Gaugler, R. \& Boush, G.M., 1978. Effects of ultraviolet radiation and sunlight on the entomogenous nematode, Neoaplectana carpocapsae. J. Invertebr. Pathol. 32, 291-296. doi: 10.1016/0022-2011(78)90191-X

Georgis, R., 1990. Formulation and application technology. In: Gaugler, R. \& Kaya, H.K. (eds). Entomopathogenic nematodes in biological control. CRC Press Inc., Boca Raton. pp. $173-191$.

Glazer, I., 1992. Survival and efficacy of Steinernema carpocapsae in an exposed environment. Biocontrol Sci. Techn. 2, 101-107. doi: $10.1080 / 09583159209355223$
Glazer, I., 2002. Survival biology. In: Gaugler, R. (ed). Entomopathogenic nematology. CAB International, Wallingford. pp. $169-188$.

Glazer, I., Klein, M., Navon, A., \& Nakache, Y., 1992a. Comparison of efficacy of entomopathogenic nematodes combined with antidesiccants applied by canopy sprays against three cotton pests (Lepidoptera: Noctuidae). J. Econ. Entomol. 85, 1636-1641. doi: 10.1093/jee/85.5.1636

Glazer, I., Nakache, Y. \& Klein, M., 1992b. Use of entomopathogenic nematodes against foliage pests. Hassadeh 72, 626-630.

Greer, D.H. \& Weston, C., 2010. Heat stress affects flowering, berry growth, sugar accumulation and photosynthesis in Vitis vinifera cv. Semillon grapevines grown in a controlled environment. Funct. Plant Biol. 37, 206214. doi: 10.1071/FP09209

Grewal, P.S., Selvan, S. \& Gaugler, R., 1994. Thermal adaptation of entomopathogenic nematodes: Niche breadth for infection, establishment, and reproduction. J. Therm. Biol. 19, 245-253. doi: 10.1016/03064565(94)90047-7

Griffin, C.T., Boemare, N.E. \& Lewis, E.E., 2005. Biology and behaviours. In: Grewal, P.S., Ehlers, R.-U. \& Shapiro-Ilan, D.I. (eds). Nematodes as biocontrol agents. CAB International, Wallingford. pp. $47-64$.

Hattingh, V., Cilliers, C.J. \& Bedford, E.C.G., 1998 ( $2^{\text {nd }}$ ed $)$. Citrus mealybugs. In: Bedford, E.C.G., Van den Berg, M.A. \& De Villiers, E.A. (eds). Citrus pests in the Republic of South Africa. Institute for Tropical and Subtropical Crops, Nelspruit. pp. $112-120$.

Head, J., Lawrence, A.J. \& Walters, K.F.A., 2004. Efficacy of the entomopathogenic nematode, Steinernema feltiae, against Bemisia tabaci in relation to plant species. J. Appl. Entomol. 128, 543-547. doi: 10.1111/j.1439-0418.2004.00882.x

Kaya, H.K. \& Stock, S.P., 1997. Techniques in insect nematology. In: Lacey, L.A. (ed). Manual of Techniques in Insect Pathology. Academic Press, San Diego, C.A. pp. $281-324$

Le Vieux, P.D. \& Malan, A.P., 2013. The potential use of entomopathogenic nematodes to control Planococcus ficus (Signoret) (Hemiptera: Pseudococcidae). S. Afr. J. Enol. Vitic. 34, 296-306.

Le Vieux, P.D. \& Malan, A.P., 2015. Prospects for using entomopathogenic nematodes to control the vine mealybug, Planococcus ficus, in South African vineyards. S. Afr. J. Enol. Vitic. 36, 59-70.

Lello, E.R., Patel, M.N., Matthews, G.A. \& Wright, D.J., 1996. Application technology for entomopathogenic nematodes against foliar pests. Crop Prot. 15, 567-574. Doi: 10.1016/0261-2194(96)00026-9

MacVean, C.M., Brewer, J.W. \& Capinera, J.L., 1982. Field tests of antidesiccants to extend the infection period of an entomogenous nematode, Neoaplectana carpocapsae, against the Colorado potato beetle. J. Econ. Entomol 75, 97-101. doi: 10.1093/jee/75.1.97

Mason, J.M., Matthews, G.A. \& Wright, D.J., 1998. Screening and election of adjuvants for the spray application of entomopathogenic nematodes against a foliar pest. Crop Prot. 17, 463-470. doi: 10.1016/S02612194(98)00043-X

Millar, I.M., 2002. Mealybug genera (Hemiptera: Pseudococcidae) of South Africa: Identification and review. Afr. Entomol. 10, 185-233.

Mráček, Z., 2002. Use of entomoparasitic nematodes (EPANs) in biological control. In: Upadhyay, R.K. (ed). Advances in microbial control of insect pests. Springer, Boston, MA. pp. $235-264$.

Norton, D.C., 1978. Ecology of Plant-Parasitic Nematodes. Wiley, New York. pp. $128-132$.

Odendaal, D., Addison, M.F. \& Malan, A.P., 2016. Evaluation of aboveground application of entomopathogenic nematodes for the control of diapausing codling moth (Cydia pomonella L.) under natural conditions. Afr. Entomol. 24, 61-74. doi: 10.4001/003.024.0061 
Platt, T., 2017. Investigating the above-ground application of EPNs for the control of the vine mealybug Planococcus ficus. MSc thesis, Stellenbosch university $108 \mathrm{pp}$.

Platt, T., Stokwe, N.F. \& Malan, A.P., 2018a. Potential of local entomopathogenic nematodes for control of the vine mealybug, Planococcus ficus. Afr. J. Enol. Vitic. (In Press).

Platt, T., Malan, A.P \& Stokwe, N.F., 2018b. Foliar application of Steinernema yirgalemense to control Planococcus ficus: Assessing adjuvants to improve application in the glasshouse. S. Afr. J. Enol. Vitic. (In Press).

Prinsloo, G.H \& Uys, V.M., 2015. Insects of Cultivated Plants and Natural Pastures in Southern Africa. Entomological Society of Southern Africa, Pretoria, South Africa.

Schroer, S. \& Ehlers, R.-U., 2004. Foliar application of the entomopathogenic nematode Steinernema carpocapsae for biological control of diamondback moth larvae (Plutella xylostella). Biol. Control. 33, 81-86. doi: 10.1016/j. biocontrol.2004.12.009

Shapiro, M., Mclane, W. \& Bell, R., 1985. Laboratory evaluation of selected chemicals as antidesiccants for the protection of the entomogenous nematode, Steinernema feltiae (Rhabditidae, Steinernematidae) against Lymantria dispar (Lepidoptera, Lymantriidae). J. Econ. Entomol. 78, 1437 1441.

Shapiro-Ilan, D.I., Gouge, D.H., Piggott, S.J. \& Fife, J.P., 2006. Application technology and environmental considerations for use of entomopathogenic nematodes in biological control. Biol. Control 38, 124-133. doi: 10.1093/ jee/78.6.1437

TIBCO Inc., 2017. STATISTICA (data analysis software system), version 13. http://statistica.io

Van Niekerk, S. \& Malan, A.P., 2012. Potential of South African entomopathogenic nematodes (Heterorhabditidae and Steinernematidae) for control of the citrus mealybug Planococcus citri (Pseudococcidae). J. Invertebr. Pathol. 111, 166-174. doi: 10.1016/j.jip.2012.07.023

Van Niekerk, S. \& Malan, A.P., 2014a. Compatibility of Heterorhabditis zealandica and Steinernema yirgalemense with agrochemicals and biological control agents. African Entomology 22, 49-56.
Van Niekerk, S. \& Malan, A.P., 2014b. Evaluating the efficacy of a polymersurfactant formulation to improve control of Planococcus citri (Risso) (Hemiptera: Pseudococcidae) under simulated natural conditions. Afr. Pl. Prot. 17, 1-9 http://reference.sabinet.co.za/document/EJC146102

Van Niekerk \& Malan, A.P. 2015. Adjuvants to improve aerial control of the citrus mealybug Planococcus citri (Hemiptera: Pseudococcidae) using entomopathogenic. J. Helminth. 98, 189-195. doi:10.1017/ S0022149X13000771

Van Zyl, S.A., Brink, J-C., Calitz, F.J. \& Fourie, P.H., 2010. Effects of adjuvants on deposition efficiency of fenhexamid sprays applied to Chardonnay grapevine foliage. Crop. Prot. 29, 843-852. doi: 10.1016/j. cropro.2010.04.017

Wakgari, W.M. \& Giliomee, J.H, 2004. Mealybugs and their parasitoids in apple and pear orchards in the Western Cape Province, South Africa. Afr. Plant Prot. 10, 7-11

Walton, V.M., 2003. Development of an integrated pest management system for vine mealybug, Planococcus ficus (Signoret), in vineyards in the Western Cape Province, South Africa. Thesis, Stellenbosch University, Private Bag X1, 7602 Matieland (Stellenbosch), South Africa.

Walton, V.M. \& Pringle, K.L., 2004. Vine mealybug, Planococcus ficus (Signoret) (Hemiptera: Pseudococcidae), a key pest in South African vineyards. A review. S. Afr. J. Enol. Vitic. 25, 54-62. doi: 10.21548/25-22140

Webster, J.M. \& Bronskill, J.F., 1968. Use of Gelgard M and an evaporation retardant to facilitate control of larch sawfly by a nematode-bacterium complex 1. J. Econ. Entomol. 61, 1370-1373. doi: 10.1093/jee/61.5.1370

Wilson, M. \& Gaugler, R., 2004. Factors limiting short-term persistence of entomopathogenic nematodes. J. Appl. Entomol. 128, 250-253. doi: 10.1111/j.1439-0418.2004.00814.x

Woodring, J.L., Kaya, H.K., 1988. Steinernematid and heterorhabditid nematodes: a handbook of techniques. Fayetteville: Arkansas Agricultura Experimental Station. (Southern Cooperative Series Bulletin 331).

Wright, D.J., Peters, A., Schroer, S, \& Fife, J.P., 2005. Application technology. In: Grewal, P.S., Ehlers, R.U. \& Shapiro-Ilan, D.I. (eds) Nematodes as biocontrol agents. CAB International, Wallingford. pp. 91 $-106$. 